\title{
Effect of Zinc with Special Reference to Nano Zinc Carrier on Yield, Nutrient Content and Uptake by Rice (Oryza sativa L.)
}

\author{
M.R. Apoorva ${ }^{1}$, P. Chandrasekhar Rao ${ }^{2}$ and G. Padmaja ${ }^{3}$ \\ Department of Soil science and Agricultural Chemistry, Professor Jayashankar Telangana State \\ Agricultural University, Rajendranagar, Hyderabad-500030, India \\ *Corresponding author
}

\section{A B S T R A C T}

Keywords

Nano zinc, Bio zinc, Rice, Soil application, Foliar application.

Article Info

Accepted:

14 June 2017

Available Online:

10 August 2017
A field experiment was conducted during kharif, 2015 at college farm, college of agriculture, Rajendranagar, Hyderabad to study the effect of various sources of zinc on yield, nutrient content and uptake by rice. The experiment was laid out in Randomized Block Design with 12 treatments and 3 replications. The results of the experiment revealed that the grain $\left(5355 \mathrm{~kg} \mathrm{ha}^{-1}\right)$, straw yield $\left(6347 \mathrm{~kg} \mathrm{ha}^{-1}\right)$ was recorded highest in the treatment receiving RDF+ Soil application of bio zinc @ $30 \mathrm{~kg} \mathrm{ha}^{-1}$ at harvest. The highest uptake of $\mathrm{N}, \mathrm{K}, \mathrm{Zn}$ was seen with the application of bio zinc@30kgha ${ }^{-1}$, phosphorus uptake was seen highest in RDF@120:60:40 $\mathrm{kg} \mathrm{ha}^{-1}$. The results have revealed that the application of bio zinc and nano zinc fertilizers both as soil and foliar application have resulted in obtaining the yields and nutrient uptake and are on par with the conventional $\mathrm{ZnSO}_{4}$ application.

\section{Introduction}

Rice (Oryza sativa L.) is the dominant staple food for more than $50 \%$ of world population and India ranks first in the world in terms of area of rice cultivation with $44.6 \mathrm{~m}$ ha and second in productivity of $2.96 \mathrm{t} \mathrm{ha}^{-1}$. In Telangana state, rice is grown in an area of 17 lakh ha ${ }^{-1}$ with a production of 64 lakh metric tons with a productivity of $3.6 \mathrm{t} \mathrm{ha}^{-1}$ (India Stat., 2015-2016). In India, zinc is considered as the fourth important yield limiting nutrient after nitrogen, phosphorus and potassium respectively. The critical limit of available zinc in the soil suitable for rice growth is $0.3 \mathrm{mg} \mathrm{kg}^{-1}$. The plant available zinc in Indian soils extracted with DTPA is less than $1 \%$ of total zinc (Takkar and Mann, 1975). It has been postulated that the zinc deficiency is likely to increase from $49-63 \%$ by the year 2025 as most of the marginal soils brought under cultivation are showing the symptoms of zinc deficiency. Hence, application of zinc fertilizers is essential in keeping sufficient amount of available zinc in soil solution, maintaining adequate zinc transport to seeds and for increases in the crop yield. Foliar or combined soil+foliar application of fertilizers under field conditions have proved to be highly effective and can be a practical way to maximize the zinc accumulation and uptake in grains. The efficiency of applied $\mathrm{ZnSO}_{4}$ is only 1 to $4 \%$ and most of the applied zinc is rendered unavailable to plants due to many factors such as leaching, fixation (Nair et al., 2010). 
Hence it is essential to minimize the nutrient losses in fertilizer application, increase the crop yield through the exploitation of new applications with the help of nano technology and nano materials. Nano fertilizers have unique physicochemical properties and the potential to boost the plant metabolism (Giraldo et al., 2014). The nano fertilizers or nano encapsulated nutrients might have the properties that are effective to crops, release the nutrients on demand, controlled release of chemical fertilizers that regulate the plant growth and enhanced target activity (DeRosa et al., 2010). Literally very little information exist on the application of nano zinc both in chemical and bioforms applied to soil and foliar application of these materials on rice crop under field conditions. Realizing the importance of zinc in plant growth and at the same time seriousness of its deficiency in soils and plants, the current investigation has been made to study the effect of zinc on yield, nutrient content and uptake by rice.

\section{Materials and Methods}

A field experiment was conducted during kharif, 2015 at College Farm, College of Agriculture, PJTSAU. Experiment was laid out in Randomized Block Design with 12 treatments and 3 replications. The rice variety used was MTU-1010. The treatments were viz., T1-Control (no fertilizers were applied), T2- RDF @ N, $\mathrm{P}_{2} \mathrm{O}_{5}, \mathrm{~K}_{2} \mathrm{O} @$ 120:60:40 kg ha-1 ${ }^{-1}$ T3-RDF+Soil application of $\mathrm{ZnSO}_{4} @ 25 \mathrm{kgha}^{-1}$ at transplanting, T4 and T5- RDF +Soil application of nano Zn @ $10 \mathrm{~kg} \mathrm{ha}^{-1}$ and $15 \mathrm{~kg} \mathrm{ha}^{-1}$, T6 and T7- RDF +Soil application of bio $\mathrm{Zn}$ @ $15 \mathrm{~kg} \mathrm{ha}^{-1}$ and $30 \mathrm{~kg} \mathrm{ha}^{-1}$ at transplanting, T8-RDF +foliar application of $0.2 \%$ as $\mathrm{ZnSO}_{4}$ at tillering and panicle emergence stage, T9 and T10-RDF +foliar application of $1 \mathrm{ml} \mathrm{l}^{-1}$ and $2 \mathrm{ml} \mathrm{l}^{-1}$ as nano zinc at tillering and panicle emergence stage, T11 and T12 -RDF +foliar application of $1.5 \mathrm{ml} \mathrm{l}^{-1}$ and $3 \mathrm{ml} \mathrm{l}^{-1}$ as bio zinc at tillering and panicle emergence stage. The study was taken up on a Vertisol $(\mathrm{pH}$ 8.24, $\left.\mathrm{EC}: 0.74 \mathrm{dSm}^{-1}\right)$, low in organic carbon $(0.42 \%)$, low in Nitrogen $\left(242 \mathrm{~kg} \mathrm{ha}^{-1}\right)$, high in available Phosphorus (92 $\mathrm{kg} \mathrm{P}_{2} \mathrm{O}_{5} \mathrm{ha}^{-1}$ ) and high in available Potassium (376 $\mathrm{kg} \mathrm{K}_{2} \mathrm{O} \mathrm{ha}^{-1}$ ). The DTPA extractable zinc was $0.3 \mathrm{mgkg}^{-1}$.

\section{Application of fertilizers}

The products i.e., nano zinc and bio zinc formulations were obtained from M/S. Prathishta industries, Alwal, Secunderabad. These are being manufactured by the firm. The nano zinc soil and foliar formulation had $\mathrm{Zn}$ content of $40 \mathrm{mg} \mathrm{kg}^{-1}$ and bio zinc soil and foliar formulation contains $3 \% \mathrm{Zn}$. Along with $16 \%$ organic carbon.

\section{Methodology}

The experimental field was ploughed thrice with tractor drawn cultivator followed by puddling with power tiller and later levelled uniformly. The field was divided into plots as per the design by providing bunds for individual plots and irrigation channels to irrigate the plots. Twenty five day old seedlings were transplanted at spacing of 20 $\times 15 \mathrm{~cm}$ with two seedlings per hill. Irrigation was given twice a week and $3-5 \mathrm{~cm}$ of standing water was maintained until 2 weeks before harvest. The treatments were evaluated on the basis of yield, nutrient contents. The nutrient uptake was computed using the formula

\footnotetext{
1. Nutrient uptake $\left(\mathrm{kg} \mathrm{ha}^{-1}\right)=$ Nutrient content $(\%)$ x yield $\left(\mathrm{kg} \mathrm{ha}^{-1}\right)$ 
2. Zinc Nutrient uptake $\left(\mathrm{g} \mathrm{ha}^{-1}\right)=\frac{\text { Zinc content }\left(\mathrm{mg} \mathrm{kg}^{-1}\right) \times \text { yield }\left(\mathrm{kg} \mathrm{ha}^{-1}\right)}{}$

1000

3. Methods employed for determination of the chemical composition of plant samples

\begin{tabular}{lll}
\hline Nutrient & Method employed & Reference \\
\hline $\mathrm{N}$ & Micro Kjeldahl $\left(\mathrm{H}_{2} \mathrm{SO}_{4}: \mathrm{H}_{2} \mathrm{O}_{2}\right)$ & Piper, (1966) \\
$\mathrm{P}$ & Spectrophotometer & Piper, (1966) \\
$\mathrm{K}$ & $\begin{array}{l}\text { Flame photometer } \\
\text { Atomic absorption }\end{array}$ & spectrophotometer \\
$\mathrm{Zn}$ & (AAS) & Lindsay and Norvell (1978)
\end{tabular}

The recorded data were subjected to statistical analysis using the analysis of variance technique for randomized block design as suggested by Panse and Sukhame (1978).

\section{Results and Discussion}

The results obtained from the present investigation on yield, nutrient content and uptake by test crop was discussed in following heads.

\section{Effect of various sources of zinc on yield of rice}

The data pertaining to yield is represented in table 1 . There is a significant difference seen among the treatments related to grain yield, the treatment receiving $\mathrm{RDF}+$ Soil application of bio zinc@30 kg ha ${ }^{-1}(5355 \mathrm{~kg}$ $\mathrm{ha}^{-1}$ ) recorded the highest grain yield and was on par with RDF + foliar spray of $0.2 \%$ $\mathrm{ZnSO}_{4}\left(5268 \mathrm{~kg} \mathrm{ha}^{-1}\right), \mathrm{RDF}+$ Foliar spray of $1 \mathrm{ml} \mathrm{l}^{-1}$ as nano zinc $\left(5247 \mathrm{~kg} \mathrm{ha}^{-1}\right)$. The lowest grain yield was recorded in the treatment receiving RDF@120:60:40 kg ha ${ }^{-1}$ $\left(3768 \mathrm{~kg} \mathrm{ha}^{-1}\right)$ followed by control $(2604 \mathrm{~kg}$ $\mathrm{ha}^{-1}$ ). The highest straw yield was recorded in the treatment receiving RDF+ Soil application of bio zinc @30 kg ha ${ }^{-1}(6347 \mathrm{~kg}$ $\mathrm{ha}^{-1}$ ) and was on par with RDF +foliar spray of $0.2 \% \mathrm{ZnSO}_{4}\left(6258 \mathrm{~kg} \mathrm{ha}^{-1}\right), \mathrm{RDF}+$ foliar spray of $1 \mathrm{ml} \mathrm{l}^{-1}$ as nano zinc $\left(6189 \mathrm{~kg} \mathrm{ha}^{-1}\right)$. Compared to all the treatments the lowest straw yield was recorded in the treatment receiving RDF@120:60:40 kg ha ${ }^{-1}$ (4621 kg $\mathrm{ha}^{-1}$ ) followed by control (3324 $\mathrm{kg} \mathrm{ha}^{-1}$ ). Keram et al., (2012) reported that the higher grain and straw yield with zinc fertilizer application might be due to the fact that zinc plays an important role in biosynthesis of IAA and initiation of primordial for reproductive part which have favored the metabolic reaction within plant.

\section{Essential elements content in grain and straw}

The major and micro elements were determined from grain and straw samples of the rice collected at the time of harvest and the results revealed that at harvest the highest $\mathrm{N}$ content in grain was seen in the treatment receiving RDF+ Soil application of $\mathrm{ZnSO}_{4} @$ $25 \mathrm{~kg} \mathrm{ha}^{-1}$ which was on par with RDF +foliar spray of $0.2 \% \mathrm{ZnSO}_{4}$. In straw the highest $\mathrm{N}$ content was seen in the treatment receiving $\mathrm{RDF}+$ Soil application of $\mathrm{ZnSO}_{4} @ 25 \mathrm{~kg} \mathrm{ha}^{-1}$ which was on par with RDF+ Soil 
application of bio zinc @ $30 \mathrm{~kg} \mathrm{ha}^{-1}$. The P content was highest in the treatment receiving RDF@120:60:40 kg ha ${ }^{-1}$ in both grain and straw. The highest $\mathrm{K}$ content in grain and straw was seen in the treatment receiving RDF+ Soil application of bio zinc @30 kg ha ${ }^{-1}$ which was on par with RDF + foliar spray of $0.2 \% \mathrm{ZnSO}_{4}$. The $\mathrm{Zn}$ content in both grain and straw was seen highest in the treatment receiving $\mathrm{RDF}+$ Soil application of bio zinc @30 kg ha ${ }^{-1}$. An appraisal of data given in table 1 showed that the different treatments of zinc significantly increased nitrogen content in grain as compared to that of straw. The higher nitrogen content in grain could be due to zinc application since zinc is essential for synthesis of DNA and RNA and for metabolisms for the production of carbohydrate, lipids and proteins. The phosphorus content in grain and straw was found to decrease with the application of zinc. It might be due to the antagonistic effect of zinc on $\mathrm{P}$ absorption. Zinc was found to inhibit the translocation of $\mathrm{P}$ from root to top. The $\mathrm{K}$ content was found to increase with the application of zinc this might be due to the synergistic interaction between zinc and potassium.

\section{Essential elements uptake by grain and straw}

The perusal of the data given in table 2 indicated that at harvest the highest uptake in grain was seen in the treatment receiving $\mathrm{RDF}+$ foliar spray of $0.2 \% \mathrm{ZnSO}_{4}(67.7 \mathrm{~kg}$ $\mathrm{ha}^{-1}$ ), followed by RDF+ Soil application of bio zinc@30 kg ha ${ }^{-1}$. In straw the highest uptake of nitrogen was seen in the treatment receiving RDF+ Soil application of bio zinc @30 kg ha ${ }^{-1}\left(38.6 \mathrm{~kg} \mathrm{ha}^{-1}\right)$ which was followed by $\mathrm{RDF}+$ foliar spray of $0.2 \%$ $\mathrm{ZnSO}_{4}\left(37.0 \mathrm{~kg} \mathrm{ha}^{-1}\right), \mathrm{RDF}+$ Soil application of $\mathrm{ZnSO}_{4} @ 25 \mathrm{~kg} \mathrm{ha}^{-1}\left(36.4 \mathrm{~kg} \mathrm{ha}^{-1}\right), \mathrm{RDF}+$ foliar spray of $1 \mathrm{ml} \mathrm{l}^{-1}$ as nano zinc $(35.5 \mathrm{~kg}$ $\left.\mathrm{ha}^{-1}\right), \mathrm{RDF}+$ foliar spray of $1.5 \mathrm{ml} \mathrm{l}^{-1}$ as bio zinc(34.1 kg ha $\left.{ }^{-1}\right)$. The lowest straw uptake was recorded in control (9.1 $\left.\mathrm{kg} \mathrm{ha}^{-1}\right)$, followed by RDF @ 120:60:40 kg ha- ${ }^{-1}$ (15.8 $\left.\mathrm{kg} \mathrm{ha}^{-1}\right)$. The highest uptake of phosphorus in grain $\left(21.5 \mathrm{~kg} \mathrm{ha}^{-1}\right)$ and straw (5.08 $\mathrm{kg} \mathrm{ha}^{-1}$ ) was recorded in the treatment receiving RDF@ 120:60:40 kg ha ${ }^{-1}$.

The highest uptake of potassium in grain $\left(26.0 \mathrm{~kg} \mathrm{ha}^{-1}\right)$ and straw $\left(109.7 \mathrm{~kg} \mathrm{ha}^{-1}\right)$ was seen in the treatment receiving $\mathrm{RDF}+$ Soil application of bio zinc @30 kg ha ${ }^{-1}$. The lowest uptake was recorded in control grain (6.5 kg ha ${ }^{-1}$ ), straw (59.2 $\left.\mathrm{kg} \mathrm{ha}^{-1}\right)$. The highest uptake of zinc in grain was recorded in the treatment receiving $\mathrm{RDF}+$ Soil application of bio zinc @ $30 \mathrm{~kg} \mathrm{ha}^{-1}(170.4 \mathrm{~g}$ $\mathrm{ha}^{-1}$ ) which was on par with $\mathrm{RDF}+$ foliar spray of $0.2 \% \mathrm{ZnSO}_{4}\left(160.1 \mathrm{~g} \mathrm{ha}^{-1}\right), \mathrm{RDF}+$ foliar spray of $1 \mathrm{ml} \mathrm{l}^{-1}$ as nano zinc $(152.7 \mathrm{~g}$ $\left.\mathrm{ha}^{-1}\right)$. The lowest was recorded in control (29.3 $\left.\mathrm{g} \mathrm{ha}^{-1}\right)$. The highest uptake of zinc in straw was recorded in the treatment receiving RDF+ Soil application of bio zinc @ $30 \mathrm{~kg}$ $\mathrm{ha}^{-1}\left(238.8 \mathrm{~g} \mathrm{ha}^{-1}\right)$ which was on par with $\mathrm{RDF}+$ foliar spray of $0.2 \% \mathrm{ZnSO}_{4}(216.3 \mathrm{~g}$ $\left.\mathrm{ha}^{-1}\right)$. This was followed by $\mathrm{RDF}+$ foliar spray of $1 \mathrm{ml} \mathrm{l}^{-1}$ as nano zinc $\left(185.0 \mathrm{~g} \mathrm{ha}^{-1}\right)$. The lowest was recorded in control $(63.2 \mathrm{~g}$ $\mathrm{ha}^{-1}$ ).

The results indicated that application of zinc increased the $\mathrm{N}$ and $\mathrm{K}$ uptake and this could be attributed to the synergistic effect which might be due to increase enzymatic activity by $\mathrm{Zn}$ application. Further the commercial method of application of $\mathrm{ZnSO}_{4} @ 25 \mathrm{~kg} \mathrm{ha}^{-1}$ and foliar application of $0.2 \% \mathrm{ZnSO}_{4}$ spray might proved to be increasing the yields.

However the results have clearly brought out the fact that application of bio zinc and nano zinc fertilizers both as soil and foliar application have resulted in obtaining the yields and on par with the conventional zinc application. 
Table.1 Effect of various sources of zinc on yield, nutrient content in grain and straw of rice

\begin{tabular}{|c|c|c|c|c|c|c|c|c|c|c|c|}
\hline \multirow[t]{2}{*}{ S.No } & \multirow[t]{2}{*}{ Treatments } & \multicolumn{2}{|c|}{ Yield $\left(\mathrm{kg} \mathrm{ha}^{-1}\right)$} & \multicolumn{2}{|c|}{$\mathrm{N}$ content $(\%)$} & \multicolumn{2}{|c|}{$P$ content $(\%)$} & \multicolumn{2}{|c|}{$K$ content $(\%)$} & \multicolumn{2}{|c|}{$\begin{array}{l}\text { Zn content } \\
\left(\mathrm{mg} \mathrm{kg}^{-1}\right) \\
\end{array}$} \\
\hline & & Grain & Straw & Grain & Straw & Grain & Straw & Grain & Straw & Grain & Straw \\
\hline T1 & Control(no fertilizers were applied) & 2604 & 3324 & 0.70 & 0.20 & 0.26 & 0.02 & 0.20 & 1.00 & 11.7 & 15.0 \\
\hline $\mathrm{T} 2$ & $\begin{array}{l}\text { Recommended dose of } \quad \mathrm{N}: \mathrm{P}_{2} 0_{5}: \mathrm{K}_{2} \mathrm{O} \\
@ 120: 60: 40 \mathrm{Kg} \mathrm{ha}^{-1}\end{array}$ & 3768 & 4621 & 1.18 & 0.34 & 0.57 & 0.11 & 0.38 & 1.31 & 17.4 & 20.5 \\
\hline T3 & $\begin{array}{l}\mathrm{RDF}+\text { Soil application of } \mathrm{ZnSO}_{4} @ 25 \mathrm{Kg} \mathrm{ha}^{-1} \\
\text { at transplanting }\end{array}$ & 4807 & 5855 & 1.30 & 0.62 & 0.28 & 0.05 & 0.40 & 1.40 & 22.7 & 29.6 \\
\hline $\mathrm{T} 4$ & $\begin{array}{l}\text { RDF+ Soil application of nano zinc as } \\
\text { impregnated } \\
\text { transplanting }\end{array}$ & 3942 & 4806 & 0.85 & 0.54 & 0.39 & 0.03 & 0.36 & 1.40 & 18.0 & 23.4 \\
\hline T5 & $\begin{array}{lcc}\begin{array}{l}\text { RDF+ Soil application of nano zinc } \\
\text { impregnated } \\
\text { granules@ } 15 \mathrm{~kg} \mathrm{ha}^{-1}\end{array} & \begin{array}{l}\text { at } \\
\text { transplanting }\end{array} \\
\end{array}$ & 4043 & 4963 & 0.97 & 0.58 & 0.36 & 0.03 & 0.37 & 1.30 & 18.8 & 22.1 \\
\hline T6 & $\begin{array}{l}\text { RDF+ Soil application of bio zinc @ } 15 \mathrm{~kg} \mathrm{ha}^{-} \\
{ }^{1} \text { at transplanting }\end{array}$ & 4623 & 5531 & 0.97 & 0.54 & 0.32 & 0.03 & 0.41 & 1.35 & 20.8 & 22.5 \\
\hline $\mathrm{T} 7$ & $\begin{array}{l}\text { RDF+ Soil application of bio zinc @ 30kg ha- } \\
1 \text { at transplanting }\end{array}$ & 5355 & 6347 & 1.21 & 0.61 & 0.26 & 0.05 & 0.45 & 1.48 & 25.3 & 37.8 \\
\hline T8 & RDF+ Foliar spray of $0.2 \%$ as $\mathrm{ZnSO}_{4}$ & 5268 & 6258 & 1.29 & 0.59 & 0.38 & 0.05 & 0.42 & 1.45 & 23.4 & 34.2 \\
\hline T9 & RDF+ Foliar spray of $1 \mathrm{ml} \mathrm{l}^{-1}$ as nano zinc & 5247 & 6189 & 1.15 & 0.57 & 0.35 & 0.04 & 0.40 & 1.41 & 23.7 & 29.6 \\
\hline T10 & $\mathrm{RDF}+$ Foliar spray of $2 \mathrm{ml}^{-1}$ as nano zinc & 4370 & 5306 & 0.92 & 0.42 & 0.35 & 0.04 & 0.39 & 1.33 & 20.8 & 22.0 \\
\hline T11 & $\mathrm{RDF}+$ Foliar spray of $1.5 \mathrm{ml} \mathrm{l}^{-1}$ as bio zinc & 4740 & 5740 & 1.09 & 0.59 & 0.37 & 0.03 & 0.38 & 1.37 & 21.0 & 24.9 \\
\hline T12 & RDF+Foliar spray of $3 \mathrm{ml} \mathrm{l}^{-1}$ as bio zinc & 4625 & 5603 & 1.00 & 0.55 & 0.34 & 0.02 & 0.35 & 1.35 & 20.2 & 24.4 \\
\hline & $\mathrm{SE}(\mathrm{m}) \pm$ & 71.5 & 70.8 & 0.021 & 0.016 & 0.012 & 0.007 & 0.019 & 0.014 & 1.39 & 1.41 \\
\hline & $\mathrm{CD}(\mathrm{P}=0.05)$ & 209.7 & 207.8 & 0.06 & 0.04 & 0.035 & 0.020 & 0.05 & 0.04 & 4.12 & 4.18 \\
\hline
\end{tabular}


Table.2 Effect of various sources of zinc on nutrient uptake in grain and straw of rice

\begin{tabular}{|c|c|c|c|c|c|c|c|c|c|}
\hline \multirow[t]{2}{*}{$\begin{array}{ll}\text { S.No } \\
\end{array}$} & \multirow[t]{2}{*}{ Treatments } & \multicolumn{2}{|c|}{ N uptake } & \multicolumn{2}{|c|}{ P uptake } & \multicolumn{2}{|c|}{ K uptake } & \multicolumn{2}{|c|}{$\begin{array}{c}\text { Zn uptake } \\
\left(\mathrm{g} \mathrm{ha}^{-1}\right)\end{array}$} \\
\hline & & Grain & Straw & Grain & Straw & Grain & Straw & Grain & Straw \\
\hline $\mathrm{T} 1$ & Control(no fertilizers were applied) & 29.9 & 9.1 & 13.24 & 1.25 & 6.5 & 59.2 & 29.3 & 63.2 \\
\hline $\mathrm{T} 2$ & $\begin{array}{l}\text { Recommended dose of } \mathrm{N}: \mathrm{P}_{2} 0_{5}: \mathrm{K}_{2} \mathrm{O} @ 120: 60: 40 \\
\mathrm{Kg} \mathrm{ha}^{-1}\end{array}$ & 38.6 & 15.8 & 21.55 & 5.08 & 14.4 & 63.7 & 64.8 & 90.6 \\
\hline $\mathrm{T} 3$ & $\begin{array}{l}\mathrm{RDF}+\text { Soil application of } \mathrm{ZnSO}_{4} @ 25 \mathrm{Kg} \mathrm{ha}^{-1} \text { at } \\
\text { transplanting }\end{array}$ & 62.6 & 36.4 & 14.00 & 1.60 & 18.5 & 86.4 & 107.5 & 169.1 \\
\hline $\mathrm{T} 4$ & $\begin{array}{l}\text { RDF+ Soil application of nano zinc as } \\
\text { impregnated granules@ } 10 \mathrm{~kg} \mathrm{ha}^{-1} \text { at transplanting }\end{array}$ & 33.5 & 26.0 & 15.54 & 1.85 & 14.4 & 76.9 & 68.2 & 102.2 \\
\hline T5 & $\begin{array}{l}\text { RDF+ Soil application of nano zinc as } \\
\text { impregnated granules@ } 15 \mathrm{~kg} \mathrm{ha}^{-1} \text { at transplanting }\end{array}$ & 39.1 & 28.8 & 14.72 & 1.65 & 16.4 & 79.8 & 79.0 & 111.9 \\
\hline T6 & $\begin{array}{l}\text { RDF+ Soil application of bio zinc @ } 15 \mathrm{~kg} \mathrm{ha}^{-1} \text { at } \\
\text { transplanting }\end{array}$ & 44.8 & 30.0 & 14.89 & 1.75 & 17.3 & 80.6 & 88.3 & 124.8 \\
\hline $\mathrm{T} 7$ & $\begin{array}{l}\text { RDF+ Soil application of bio zinc @ } 30 \mathrm{~kg} \mathrm{ha}^{-1} \text { at } \\
\text { transplanting }\end{array}$ & 64.6 & 38.6 & 13.81 & 1.67 & 26.0 & 109.7 & 170.4 & 238.8 \\
\hline T8 & $\mathrm{RDF}+$ Foliar spray of $0.2 \%$ as $\mathrm{ZnSO}_{4}$ & 67.7 & 37.0 & 18.83 & 2.31 & 22.3 & 101.9 & 160.1 & 216.3 \\
\hline T9 & $\mathrm{RDF}+$ Foliar spray of $1 \mathrm{ml} \mathrm{l}^{-1}$ as nano zinc & 60.5 & 35.5 & 18.31 & 2.20 & 20.8 & 92.7 & 152.7 & 185.0 \\
\hline T10 & $\mathrm{RDF}+$ Foliar spray of $2 \mathrm{ml} \mathrm{l}^{-1}$ as nano zinc & 40.2 & 22.1 & 16.70 & 1.49 & 16.9 & 78.4 & 76.4 & 116.5 \\
\hline T11 & $\mathrm{RDF}+$ Foliar spray of $1.5 \mathrm{ml} \mathrm{l}^{-1}$ as bio zinc & 51.7 & 34.1 & 17.69 & 1.45 & 18.0 & 84.0 & 95.3 & 143.0 \\
\hline T12 & $\mathrm{RDF}+$ Foliar spray of $3 \mathrm{ml} \mathrm{l}^{-1}$ as bio zinc & 46.3 & 30.7 & 15.80 & 1.30 & 17.5 & 80.7 & 91.1 & 135.7 \\
\hline & $\mathrm{SE}(\mathrm{m}) \pm$ & 2.0 & 1.9 & 0.68 & 0.30 & 1.0 & 1.4 & 7.2 & 10.7 \\
\hline & $\mathrm{CD}(\mathrm{P}=0.05)$ & 6.1 & 5.8 & 2.03 & 1.00 & 3.1 & 4.4 & 21.5 & 31.6 \\
\hline
\end{tabular}

One of the reasons that could be attributed in bio zinc which is encapsulated in the organic compounds i.e., either gluconates or lactates might have prevented the leaching losses of the zinc and made it available to the growth of the crop at the time of its requirement by the crop (Das, 2005), further the use of microorganism and organic matter (16\%) which might have contributed to increased microbial activity in the soil by being a source of organic carbon. In addition, use of bio zinc might contribute to the increased organic carbon status of soil in long run. The foliar application of nano zinc was found to be on par with the soil application of bio zinc and the quantity of zinc applied in the form of nano zinc material is much less and hence is easily accessible for uptake by foliage. The results are in submission with Keram (2012),
Fageria (2004) and (Morshedi and Farahbeksha, 2010).

\section{References}

Das, D.K. 2005. Molecular Soil science Research and Nanotechnology in Agriculture. $4^{\text {th }}$ Prof. S.K. Mukherjee Commemoration Lecture, $92^{\text {nd }}$ Indian Science Congress, Nirma University of Science and Technology, Ahmedabad, January 3-7, 2005.

DeRosa, M.C., Monreal, C., Schnitzer, M., Walsh, R. and Sultan, Y. 2010. Nanotechnology in fertilizers. Nature Nanotechnol., 32(5): 1234-1237.

Fageria, N.K. 2004. Dry matter, Yield and Nutrient uptake by Lowland Rice at Different Growth stages. J. Plant 
Nutrition, 27: 947-958.

Giraldo, J.P., Landry, M.P., Faltermeier, S.M., Nicholas, T.P., Iverson, N.M., Boghossian, A.A., Reuel, N.F., Hilmer, A.J., Sen, F., Brew, J.A., Strano, M.S. 2014. Plant nanobionics approach to augment photosynthesis and biochemical sensing. Nature Material.

India Stat. 2015-16. India's Comprehensive Statistical Analysis, (http://www.india stat.com).

Keram, K.S., Sharma, B.L., Sawarkar, S.D. 2012. Impact of $\mathrm{Zn}$ application on yield, Quality, Nutrients uptake and Soil fertility in a medium deep black soil (Vertisol). Int. J. Sci. Environ. Technol., 1(5): $563-571$.

Lindsay, W.L. and Norvell, W.A. 1978. Development of DTPA soil test for zinc, iron, manganese and copper. Soil Sci. Soc. America J., 43: 421-428.

Morshedia, A. and Farahbakhsh, H. 2010.
Effects of potassium and zinc on grain protein contents and yield of two wheat genotypes under soil and water salinity and alkalinity stress. Plant Ecophysiol., 2: 67-72.

Nair, R., Varghese, S.H., Nair, B.G., Maekawa, T., Yoshida, Y., Kumar, D.S. 2010. Nanoparticulate material delivery to plants. J. Plant Sci., 179: 154-163.

Panse, V.G. and Sukhatme, P.V. 1978. Statistical methods for agricultural works, Indian council of Agricultural Research, New Delhi, pp. 361.

Piper, C.S. 1966. Soil and Plant Analysis, Hans Publishers, Bombay. Pp. 137-153.

Takkar, P. and Mann, M.S. 1975. Evaluation of analytical methods for estimating available zinc and response of maize to applied zinc in major soils series of Ludhiana, Punjab. Agrochimica, 19: 420-429.

\section{How to cite this article:}

Apoorva, M.R., P. Chandrasekhar Rao and Padmaja, G. 2017. Effect of Zinc with Special Reference to Nano Zinc Carrier on Yield, Nutrient Content and Uptake by Rice (Oryza sativa L.). Int.J.Curr.Microbiol.App.Sci. 6(8): 1057-1063. doi: https://doi.org/10.20546/ijcmas.2017.608.131 